\title{
Morphology of Blood Cells, Liver and Spleen of the Desert Tortoise (Testudo graeca)
}

\author{
A. Kassab ${ }^{*}$, , S. Shousha ${ }^{2}$ and A. Fargani ${ }^{3}$ \\ ${ }^{1}$ Department of Anatomy and Embryology, Faculty of Veterinary Medicine, Benha University, Moshtohor, 13736, \\ Toukh, Egypt \\ ${ }^{2}$ Department of Physiology, Faculty of Veterinary Medicine, Benha University, Moshtohor, 13736, Toukh, Egypt \\ ${ }^{3}$ Department of Zoology, Faculty of Science, Garyounis University, Libya
}

\begin{abstract}
The morphological characteristics of peripheral blood cells, the anatomical structure of the liver and spleen were examined in desert tortoise. Forty healthy adult Testudo graeca tortoises, 20 females and 20 males were selected for this study. The tortoises were given thorough examination, and a blood sample was collected from the heart by cardiocentesis. The Wright staining method was used for classification of the blood cells. Seven different types of blood cells were determined: erythrocytes, heterophils, eosinophils, basophils, lymphocytes, monocytes and thrombocytes. Mature erythrocytes of captive Testudo graeca were nucleated ellipsoidal cells. Erythrocytes measurements for males were (length $18.76 \pm 2.81 \mu \mathrm{m} \times$ width $9.52 \pm 2.23 \mu \mathrm{m}$ ) and for females were (length $19.19 \pm 2.90 \mu \mathrm{m} \times$ width $9.84 \pm 2.50$ $\mu \mathrm{m})$. The heterophil contain large, eosinophilic, ovoid, cytoplasmic granules with eccentric nucleus. The eosinophil is distinguished by its round, eosinophilic cytoplasmic granules and the nucleus is round to oval, single or bi-lobed, and eccentrically placed within the cytoplasm. The basophil was easily identified by its deeply stained purple, large, round granules that remained tightly adhered to the centrally located nucleus. The lymphocyte contained a small amount of blue staining cytoplasm and a round nucleus with a fine reticular pattern. The monocyte contains a large amount of light bluegray, finely granular or vacuolated cytoplasm, and an oval or indented nucleus. Thrombocytes were oval-shaped cells contained round, densely stained nucleus. The liver composed of two lobes, right and left which were connected with a narrow band of connective tissue. The parenchyma of the tortoise liver is seen to be composed of intersinusoidal cords of hepatocytes. The spleen grossly appeared as round or oval structure. The parenchyma (splenic pulp) formed of lymphoid tissue and is of two distinct types; white and red pulps.

Overall, this study provides identification of the morphological characteristics of different peripheral blood cells of the tortoise Testudo graeca species as well as the anatomy of the liver and spleen, as a reference for future hematological studies of this species and may be used as a basis for comparison in clinical cases.
\end{abstract}

Keywords: Blood cells, liver, spleen, desert tortoise(Testudo graeca).

\section{INTRODUCTION}

The desert Tortoise is a member of the reptile family that is composed of snakes, lizards, crocodiles and other chelonians (turtles). Turtles are obviously different from other reptiles by the shell or box that completely covers the body. The shell is actually a part of the body and hardens about three years after hatching.

Tortoises have position in terrestrial live because some of population use the tortoises as source of protein food and use from zoological garden many research work studying the tortoises for fixed data about biological and behavioral and infectious diseases [1-3].

Hematological analyses have been described to a limited extent for captive desert tortoises and free-ranging tortoises in the western Mojave Desert, northeastern Mojave Desert, Sonoran Desert in Arizona, and Alachua and Lake Counties

*Address correspondence to this author at the Department of Anatomy and Embryology, Faculty of Veterinary Medicine, Benha University, Moshtohor, 13736, Toukh, Egypt; Tel: +20133212925;

Fax:+20132460640; E-mail: kassab_aa@yahoo.com in Florida [4-11]. Understanding of blood composition of turtles is very important for preventing and treating many diseases [12].

There are many published papers that characterize the blood of land tortoise $[1,13,14]$. Data for the gopher tortoise have included red and white blood cell counts [15], erythrocyte size measurements [16], hematocrit, specific gravity, blood volume, plasma volume, and total body water [17], percent protein [18], total protein, sialic acid [19], and calcium, sodium, magnesium, and cholesterol [20].

However, little or no previous study has presented values for a wide range of blood variables for the desert tortoise Testudo graeca.

Clarification of the morphological characteristics and classification of blood cells, especially WBCs, from the desert tortoise Testudo graeca is important because this species information could be used to assist those attempting to interpret WBC counts for clinical and research specimens in the wild. 
The anatomical structure of turtles alimentary canal wasn't fully knowledged, especially morphology and asymmetry of particular organs. The one from more interesting organs of alimentary canal is the liver, which is the energy centre of the organism and blood forming organ. The macroscopic and microscopic description of this organ in turtles introduces following scientific publications [21, 22].

Therefore, the aim of this work was firstly, identification of the morphological characteristics of different peripheral blood cells of the tortoise Testudo graeca species, as a reference for future hematological studies of this species. Secondly, Description of the macro- and micro- morphology of the blood cells forming organs especially liver and spleen.

\section{MATERIALS AND METHODS}

\section{Animals}

Forty healthy adult Testudo graeca tortoises, 20 females and 20 males were collected during two distinct trapping seasons, fall (September-October, 2006) and spring (February-March 2007). They were collected from wildlife management area in Sidi Khalifa in Libya. Captured tortoises were physically examined and the carapace and plastron length and width and body weight were recorded. Tortoises were kept in similar plastic boxes and fed green leaves and grass. They were kept under these conditions for 21 days before the start of experiment.

\section{Blood Sampling}

Tortoises were restrained manually without sedation. Blood samples were collected by cardiocentesis. Cardiac puncture has been reported as a method of choice for blood collection. This method requires a hole drilled through the plastron on the heart site (Fig. 1). The $19 \mathrm{G}$ luer needle was inserted in the heart. A total of one ml blood was collected into heparinized plastic containers from each experimental animal.

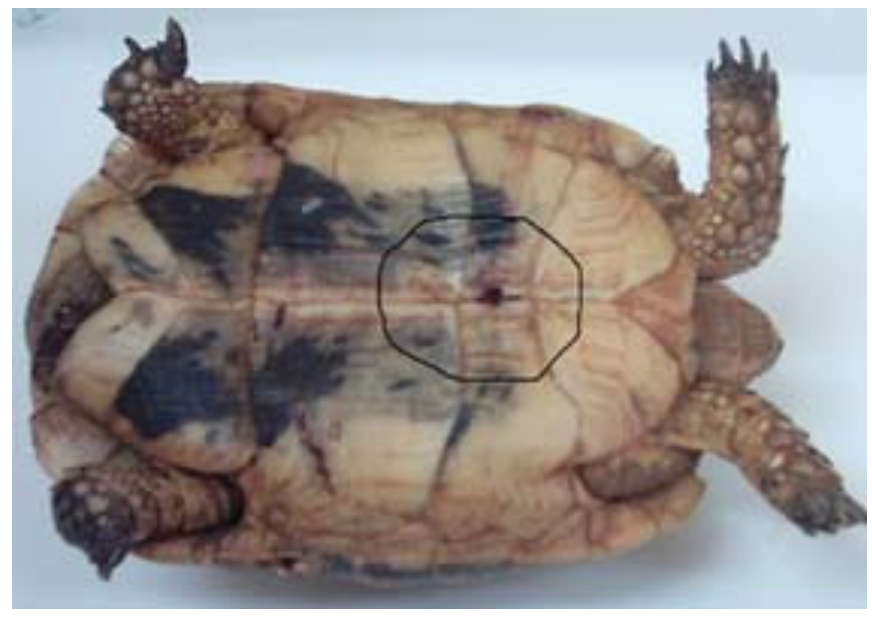

Fig. (1). Photograph of the adult tortoise (Testudo graeca) showing the site of cardiocentesis and Cardiac puncture through the plastron.

\section{Blood Cell Morphology}

Blood smears were immediately prepared and air dried. Wright's stained blood smears were used for the measurement and assessment of blood cells. Slides were treated with Wright's stain for 2 minutes, washed in running tap water for 2 minutes and rinsed in distilled water for 2 minutes. Slides were dried and mounted with Canada balsam. Four to five blood smears per individual animal were randomly selected. One hundred erythrocytes and thirty of each of thrombocytes, heterophils, eosinophils, basophils, lymphocytes and monocytes were measured via Thoma's hemocytometer by Olympus ocular micrometer (magnification power: $\times 1000$ ) [16]. The measurements included maximal length (L) and maximal width (W). Sizes of cells were calculated according to the formula $(\mathrm{L} \times \mathrm{W}$ $\times \pi) / 4[23,24]$.

\section{Preparation of Histological Sections}

Ether was used to euthanize the animals. A saw was used to cut sides of the plastron. After removal of the plastron, the liver and spleen were examined macroscopically and specimens from the liver and spleen were obtained. They were rinsed with normal saline and then transferred into $10 \%$ neutral buffered formol solution, dehydrated and embedded in paraffin. Sections of 5-6 $\mu \mathrm{m}$ in thickness were obtained and stained with Haematoxylen and eosin $(\mathrm{H} \& \mathrm{E})$ for routine histological examination [25].

The histological sections were carefully examined under an ordinary light microscope. (Carl Zeiss, Germany). Microphotography of selected microscopic fields was carried out with the aid of digital camera- computer set up.

\section{Statistical Analysis}

Numerical Data are presented as mean \pm standard deviation (S.D.). Data were analyzed for statistical significance using student $\mathrm{t}$ test. $\mathrm{P}$ value of less than 0.05 indicates significance. Confidence intervals, at $95 \%$ level, were also calculated. All statistical analyses were accomplished with the statistical package for the social sciences (SPPS 9.0, SPSS Inc. Corp., Chicago, IL, USA) computer package.

\section{RESULTS}

\section{Physical Parameters}

Carapace and plastron measurements were collected from all forty adult tortoises. The mean and standard deviation for the carapace and plastron lengths and widths are reported in Table 1. Female tortoises had longer carapace length (females: $24.3 \pm 1.69 \mathrm{~cm}$, males $22.4 \pm 1.57 \mathrm{~cm}$ ), carapace width (females: $17.4 \pm 1.63 \mathrm{~cm}$, males: $14.9 \pm 1.23 \mathrm{~cm}$ ), plastron length (females: $20.4 \pm 1.70 \mathrm{~cm}$, males: $18.4 \pm 1.53$ $\mathrm{cm}$ ), and plastron width (females: $15.5 \pm 1.53 \mathrm{~cm}$, males: $13.9 \pm 1.29 \mathrm{~cm}$ ) than males. Body weight means for females was $(646.50 \pm 18.96 \mathrm{~g})$ and for males $(628.90 \pm 28.11 \mathrm{~g})$.

\section{Red Blood Cells Morphology}

The erythrocytes of Testudo graeca (Fig. 2a) were nucleated, ellipsoid cells and their nuclei were oval and centrally located like those of the other reptile species. The cytoplasm of mature erythrocytes appeared light and dark pink and was homogeneous under Wright's stain. The nuclei of mature erythrocytes are chromophilic. They might contain prominent vacuoles (Fig. 2b). Erythrocyte measurements for males were (length $18.76 \pm 2.81 \mu \mathrm{m} \times$ width $9.52 \pm 2.23$ $\mu \mathrm{m})$ and for females were (length $19.19 \pm 2.90 \mu \mathrm{m} \times$ width $9.84 \pm 2.50 \mu \mathrm{m})$. The nucleus was centrally located and 
stained dark purple under Wright's stain. The measurements of the nucleus for males were $(6.14 \pm 0.81 \mu \mathrm{m} \times 4.44 \pm 0.88$ $\mu \mathrm{m})$ and for females were $(6.32 \pm 0.82 \mu \mathrm{m} \times 4.79 \pm 0.88$ $\mu \mathrm{m})$. Size means of the erythrocytes for males was $(140.41 \pm$ $\left.49.34 \mu^{2}\right)$ and for females $\left(142.07 \pm 54.98 \mu^{2}\right)$. Results of erythrocytes measurements are summarized in Table 2 .

Table 1. Descriptive Statistics for the Carapace, and Plastron and Weight Measurements for All Males and Females Testudo graeca

\begin{tabular}{|c|c|c|c|c|}
\hline SD & Mean & $\mathbf{N}$ & Sex & Variable \\
\hline \pm 28.1105 & 628.9000 & 20 & M & \multirow{2}{*}{ Body weight (g) } \\
\hline \pm 18.9695 & 646.5000 & 20 & $\mathrm{~F}$ & \\
\hline \pm 1.5720 & 22.4500 & 20 & M & \multirow{2}{*}{ Carapace Length $(\mathrm{cm})$} \\
\hline \pm 1.6944 & 24.3500 & 20 & $\mathrm{~F}$ & \\
\hline \pm 1.2344 & 14.9500 & 20 & M & \multirow{2}{*}{ Carapace width $(\mathrm{cm})$} \\
\hline \pm 1.6351 & 17.4000 & 20 & $\mathrm{~F}$ & \\
\hline \pm 1.5355 & 18.4000 & 20 & M & \multirow{2}{*}{ Plastron Length $(\mathrm{cm})$} \\
\hline \pm 1.7006 & 20.4500 & 20 & $\mathrm{~F}$ & \\
\hline \pm 1.2937 & 13.9000 & 20 & M & \multirow{2}{*}{ Plastron width (cm) } \\
\hline \pm 1.5390 & 15.5000 & 20 & $\mathrm{~F}$ & \\
\hline
\end{tabular}

\section{White Blood Cells Morphology Granulocytes}

Granulocytes include the leukocytes that contain specific granules that identify the cell lineage. These cells include heterophils, eosinophils, and basophils.

Heterophils - The heterophil (Fig. 2c) was the most abundant leukocyte found in blood. It is equivalent to a mammalian neutrophil. It contained large, eosinophilic and round cytoplasmic granules. The cytoplasm, which can be difficult to visualize, was light blue or clear. The nucleus was frequently displaced toward the edge of the cell and

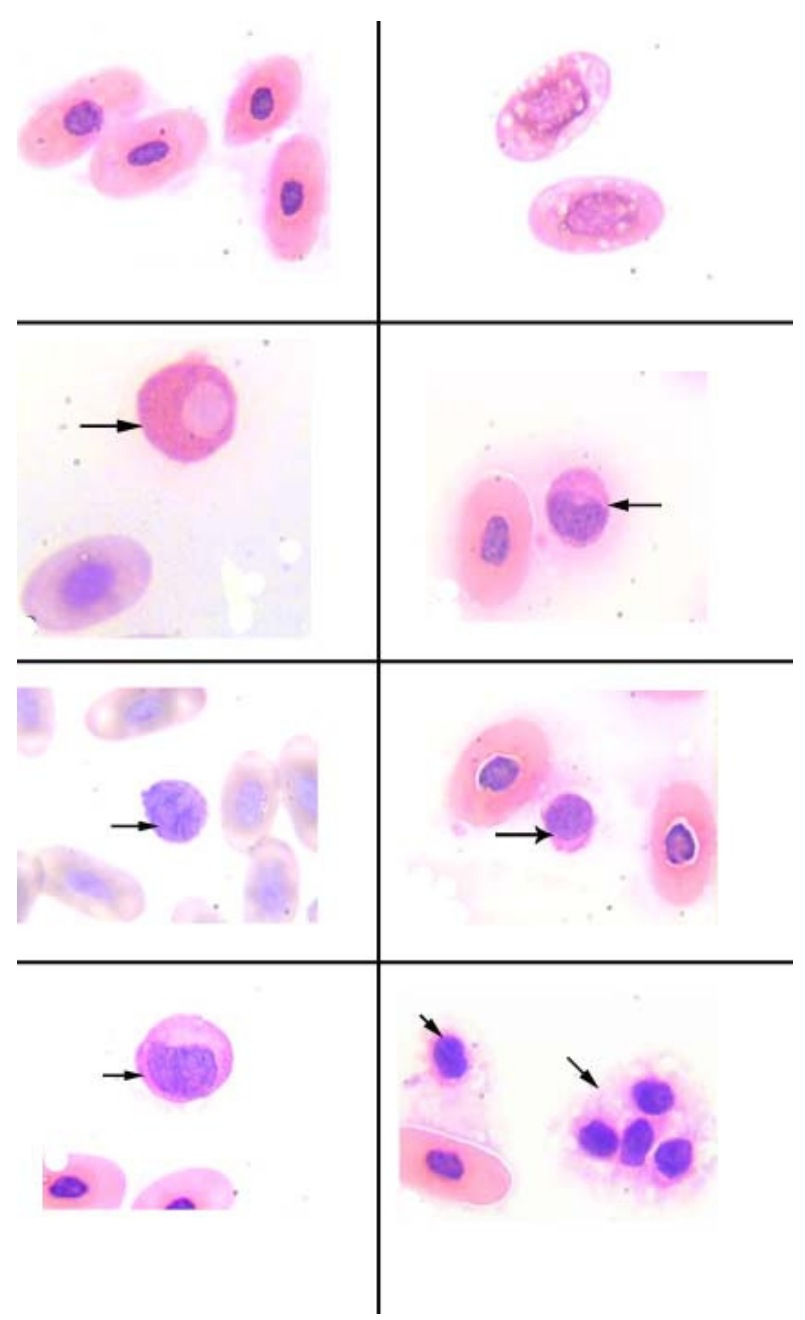

Fig. (2). Light micrograph of Wright's stained blood smears from the desert tortoise Testudo graeca showing: (a) Erythrocytes, (b) Erythrocytes with prominent vacuoles, (c) Heterophil (arrow) and erythrocyte, (d) Eosinophil (arrow) and erythrocyte, (e) Basophil (arrow) and erythrocyte, (f) Lymphocyte (arrow) and erythrocyte, (g) Monocyte (arrow) and erythrocyte, (h) Clumps of thrombocytes (arrows) and erythrocyte. (Wright stain $\times 1000)$.

Table 2. Means of the Erythrocytes and Erythrocytes Nuclei Dimensions and Erythrocytes Size Means of the Male and Female Testudo graeca

\begin{tabular}{|c|c|c|c|c|c|c|}
\hline $\mathbf{P}$ & Confidence Interval (95\%) & SD & Mean & $\mathbf{N}$ & Sex & Variable \\
\hline \multirow{2}{*}{0.279} & $18.2122-19.3274$ & \pm 2.8100 & 18.7698 & 100 & M & \multirow{2}{*}{ Erythrocytes Length $(\mu)$} \\
\hline & $18.6231-19.7749$ & \pm 2.9024 & 19.1990 & 100 & $\mathrm{~F}$ & \\
\hline \multirow{2}{*}{0.077} & $9.0829-9.9691$ & \pm 2.2331 & 9.5260 & 100 & M & \multirow{2}{*}{ Erythrocytes Width $(\mu)$} \\
\hline & $9.3430-10.3390$ & \pm 2.5096 & 9.8410 & 100 & $\mathrm{~F}$ & \\
\hline \multirow{2}{*}{0.128} & $5.9777-6.3031$ & \pm 0.8199 & 6.1404 & 100 & M & \multirow{2}{*}{ Nuclear Length $(\mu)$} \\
\hline & $6.1617-6.4871$ & \pm 0.8200 & 6.3244 & 100 & $\mathrm{~F}$ & \\
\hline \multirow{2}{*}{$0.008^{*}$} & $4.2710-4.6234$ & \pm 0.8880 & 4.4472 & 100 & $\mathrm{M}$ & \multirow{2}{*}{ Nuclear Width $(\mu)$} \\
\hline & $4.6178-4.9702$ & \pm 0.8878 & 4.7940 & 100 & $\mathrm{~F}$ & \\
\hline \multirow{2}{*}{0.128} & $130.6241-150.2081$ & \pm 49.3495 & 140.4161 & 100 & M & \multirow{2}{*}{ Erythrocytes Size $\left(\mu^{2}\right)$} \\
\hline & $141.1660-162.9880$ & \pm 54.9891 & 142.0770 & 100 & $\mathrm{~F}$ & \\
\hline
\end{tabular}


appeared basophilic with dense chromatin. Heterophil measurements in males were (length $15.53 \pm 2.7 \mu \mathrm{m}$ and width $13.49 \pm 2.60 \mu \mathrm{m}$ ) and in females were (length $15.48 \pm$ $2.52 \mu \mathrm{m}$ and width $12.88 \pm 2.54 \mu \mathrm{m})$. Heterphils size meansof the male was $\left(172.72 \pm 58.60 \mu^{2}\right)$ and in the female was $\left(167.05 \pm 49.24 \mu^{2}\right)$. Results of heterophils measurements are summarized in Table 3.

Eosinophils - The eosinophil (Fig. 2d) was distinguished by its round eosinophilic cytoplasmic granules which do not fill the colorless cytoplasm. The nucleus contains coarse, clumped chromatin and stained red. It was round to oval, single or bi-lobed and eccentrically placed within the cytoplasm. Its measurements in males were (length $14.48 \pm$ $1.54 \mu \mathrm{m}$ and width $10.72 \pm 1.7 \mu \mathrm{m}$ ) and in females were (length $14.19 \pm 1.81 \mu \mathrm{m}$ and width $10.08 \pm 1.3 \mu \mathrm{m}$ ). Eosinophil size means of the male was $\left(122.84 \pm 26.24 \mu^{2}\right)$ and in female was $\left(118.33 \pm 28.72 \mu^{2}\right)$. Results of eosinophils measurements are summarized in Table 4.

Basophils - The basophil (Fig. 2e) was easily identified by its deeply stained purple, large, round granules that remained tightly adhered to the centrally located nucleus. In some instances the granules completely occluded the nucleus. Its measurements in males were (length $12.18 \pm$ $1.02 \mu \mathrm{m}$ and width $11.91 \pm 0.98 \mu \mathrm{m}$ ) and in females were (length $12.56 \pm 1.14 \mu \mathrm{m}$ and width $12.26 \pm 1.18 \mu \mathrm{m}$ ). Basophil size means of the male was $\left(114.89 \pm 18.82 \mu^{2}\right)$ and in female was $\left(121.99 \pm 22.06 \mu^{2}\right)$. Results of basophils measurements are summarized in Table $\mathbf{5}$.

\section{Mononuclear Cells}

The mononuclear cells include lymphocytes and monocytes. These cells generally lack significant lobulation

Table 3. Means of the Heteroplils Dimensions and Heterophils Size Means of the Male and Female Testudo graeca

\begin{tabular}{|c|c|c|c|c|c|c|}
\hline $\mathbf{P}$ & Confidence Interval (95\%) & SD & Mean & No. Cells & Sex & Variable \\
\hline \multirow[t]{2}{*}{0.959} & $14.5132-16.5501$ & \pm 2.7275 & 15.5317 & 30 & M & \multirow{2}{*}{ Heterophil Length $(\mu$} \\
\hline & $14.5470-16.4317$ & \pm 2.5236 & 15.4893 & 30 & $\mathrm{~F}$ & \\
\hline \multirow[t]{2}{*}{0.396} & $12.5229-14.4691$ & \pm 2.6061 & 13.4960 & 30 & M & \multirow{2}{*}{ HeterophilWidth $(\mu)$} \\
\hline & $11.9334-13.8312$ & \pm 2.5412 & 12.8823 & 30 & $\mathrm{~F}$ & \\
\hline \multirow[t]{2}{*}{0.396} & $150.837-194.6023$ & \pm 58.6019 & 172.7200 & 30 & M & \multirow{2}{*}{ Heterophil Size $\left(\mu^{2}\right)$} \\
\hline & $138.668-175.4446$ & \pm 49.2439 & 167.0567 & 30 & $\mathrm{~F}$ & \\
\hline
\end{tabular}

*P value of less than 0.05 indicates a significant difference between the compared means of male and female tortoises.

Table 4. Means of the Eosinophils Dimensions and Eosinophils Size Means of the Male and Female Testudo graeca

\begin{tabular}{|c|c|c|c|c|c|c|}
\hline $\mathbf{P}$ & Confidence Interval (95\%) & SD & Mean & No. Cells & Sex & Variable \\
\hline \multirow{2}{*}{0.516} & $13.9055-15.0585$ & \pm 1.5439 & 14.482 & 30 & M & \multirow{2}{*}{ Eosinophils Length $(\mu)$} \\
\hline & $13.5183-14.8717$ & \pm 1.8122 & 14.195 & 30 & $\mathrm{~F}$ & \\
\hline \multirow{2}{*}{0.323} & $10.0895-11.3645$ & \pm 1.7072 & 10.727 & 30 & M & \multirow{2}{*}{ Eosinophils Width $(\mu)$} \\
\hline & $8.2145-17.9602$ & \pm 1.3049 & $10 . .087$ & 30 & $\mathrm{~F}$ & \\
\hline \multirow{2}{*}{0.514} & $113.041-132.6403$ & \pm 26.2439 & 122.840 & 30 & M & \multirow{2}{*}{ Eosinophils Size $\left(\mu^{2}\right)$} \\
\hline & $107.614-129.0645$ & \pm 28.7226 & 118.339 & 30 & $\mathrm{~F}$ & \\
\hline
\end{tabular}

*P value of less than 0.05 indicates a significant difference between the compared means of male and female tortoises.

Table 5. Means of the Basophils Dimensions and Basophils Size Means of the Male and Female Testudo graeca

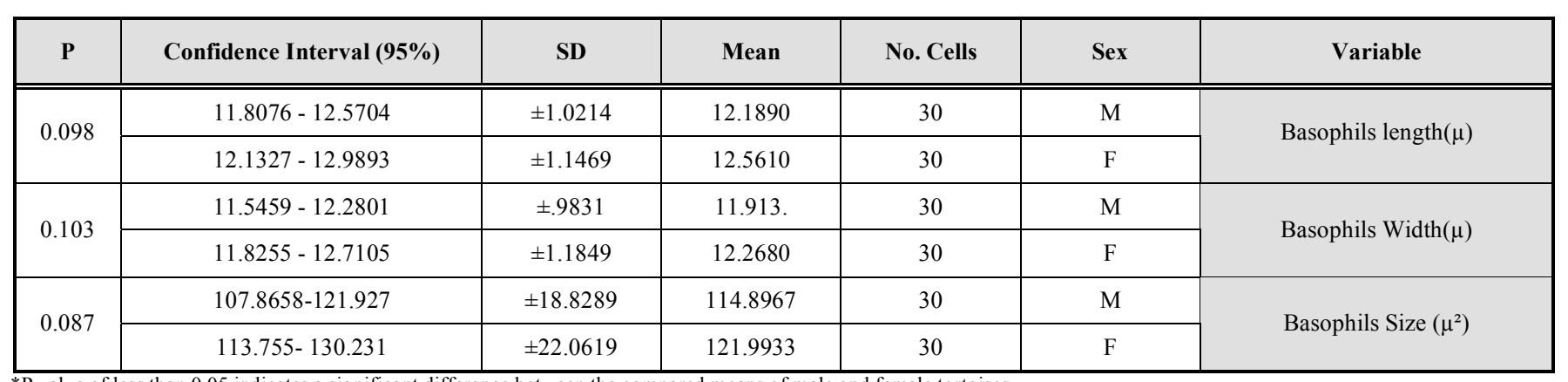

*P value of less than 0.05 indicates a significant difference between the compared means of male and female tortoises. 
Table 6. Means of the Lymphocytes Dimensions and Lymphocytes Size Means of the Male and Female Testudo graeca

\begin{tabular}{|c|c|c|c|c|c|c|}
\hline $\mathbf{P}$ & Confidence Interval (95\%) & SD & Mean & No. Cells & Sex & Variable \\
\hline \multirow{2}{*}{0.100} & $8.3452-9.9728$ & \pm 2.1794 & 9.1590 & 30 & M & \multirow{2}{*}{ Lymphocytes Length $(\mu)$} \\
\hline & $9.1898-11.0102$ & \pm 2.4377 & 10.1000 & 30 & $\mathrm{~F}$ & \\
\hline \multirow{2}{*}{0.055} & $7.0388-8.3688$ & \pm 1.7778 & 7.7027 & 30 & M & \multirow{2}{*}{ Lymphocytes Width $(\mu)$} \\
\hline & $7.9072-9.5195$ & \pm 2.1590 & 8.7133 & 30 & $\mathrm{~F}$ & \\
\hline \multirow{2}{*}{0.047} & $47.9936-68.3131$ & \pm 27.2083 & 58.1533 & 30 & M & \multirow{2}{*}{ Lymphocytes Size $\left(\mu^{2}\right)$} \\
\hline & $60.7868-85.3065$ & \pm 32.0832 & 73.0467 & 30 & $\mathrm{~F}$ & \\
\hline
\end{tabular}

*P value of less than 0.05 indicates a significant difference between the compared means of male and female tortoises.

of the nucleus and do not contain an abundance of cytoplasmic granules.

Lymphocytes - The lymphocytes (Fig. 2f) contained a small amount of blue staining cytoplasm and a round nucleus with a fine reticular pattern. The lymphocyte was more spheroid than the thrombocyte, with a nuclear to cytoplasmic ratio of greater than one. Its measurements in males were (length $9.15 \pm 2.17 \mu \mathrm{m}$ and width $7.70 \pm 1.77 \mu \mathrm{m}$ ) and in females were (length $10.10 \pm 2.43 \mu \mathrm{m}$ and width $8.71 \pm 2.15$ $\mu \mathrm{m})$. Lymphocytes size means of the male was (58.15 \pm $\left.27.20 \mu^{2}\right)$ and in female was $\left(73.04 \pm 32.08 \mu^{2}\right)$. Results of lymphocytes measurements are summarized in Table 6.

Monocytes - The monocyte (Fig. 2g) contained a large amount of light blue-gray, finely granular or vacuolated cytoplasm and an oval or indented nucleus with a dense chromatin pattern. Monocytes in males were (length $14.67 \pm$ $2.53 \mu \mathrm{m}$ and width $10.28 \pm 2.05 \mu \mathrm{m})$ and in females were (length $14.99 \pm 2.83 \mu \mathrm{m}$ and width $10.91 \pm 1.93$ ). Size means of the monocyte in male was $\left(118.32 \pm 49.34 \mu^{2}\right)$ and in female was $\left(125.74 \pm 59.97 \mu^{2}\right)$. Results of monocytes measurements are summarized in Table 7.

Thrombocytes - The thrombocytes (Fig. 2h) were ellipsoidal cells that contained round densely stained nucleus. The cytoplasm was clear and the thrombocytes tended to clump together. These latter two identifying characteristics help in distinguishing the thrombocytes from the lymphocytes. The thrombocytes in males were (length $6.18 \pm 0.92 \times$ width $4.59 \pm 0.95$ ) and in females were (length $6.29 \pm 1.00$ and width $4.62 \pm 1.02)$. Thrombocyte size means of the male was $\left(22.70 \pm 7.14 \mu^{2}\right)$ and in female was $(23.21 \pm$ $\left.7.59 \mu^{2}\right)$. Results of thrombocytes measurements are summarized in Table 8.

\section{Morphological and Histological Results of the Liver}

The liver of tortoise is situated in the abdominal cavity transverse to the long axis of the body. It is dark red in the fresh condition. It was composed of two lobes, right and left (Fig. 3). The left lobe is slight larger than the right one. The

Table 7. Means of the Monocytes Dimensions and Monocytes Size of the Male Female Testudo graeca

\begin{tabular}{|c|c|c|c|c|c|c|}
\hline $\mathbf{P}$ & Confidence Interval (95\%) & SD & Mean & No. Cells & Sex & Variable \\
\hline \multirow{2}{*}{0.639} & $13.7219-15.618$ & \pm 2.5399 & 14.6703 & 30 & M & \multirow{2}{*}{ Monocytes length $(\mu)$} \\
\hline & $13.9320-16.052$ & \pm 2.8387 & 14.9920 & 30 & $\mathrm{~F}$ & \\
\hline \multirow{2}{*}{0.227} & $9.5126-11.0494$ & \pm 2.0578 & 10.2810 & 30 & M & \multirow{2}{*}{ Monocytes Width $(\mu)$} \\
\hline & $10.1954-11.642$ & \pm 1.9378 & 10.9190 & 30 & $\mathrm{~F}$ & \\
\hline \multirow{2}{*}{0.625} & $99.8959-136.74$ & \pm 49.3461 & 118.3220 & 30 & M & \multirow{2}{*}{ Monocytes Size $\left(\mu^{2}\right)$} \\
\hline & $103.349-148.14$ & \pm 59.9797 & 125.7467 & 30 & $\mathrm{~F}$ & \\
\hline
\end{tabular}

*P value of less than 0.05 indicates a significant difference between the compared means of male and female tortoises.

Table 8. Means of the Thrombocytes Dimensions and Thrombocytes Size Means of the Male and Female Testudo graeca

\begin{tabular}{|c|c|c|c|c|c|c|}
\hline $\mathbf{P}$ & Confidence Interval (95\%) & SD & Mean & No. cells & Sex & Variable \\
\hline \multirow{2}{*}{0.682} & $5.8425-6.5335$ & \pm 0.9253 & 6.1880 & 30 & M & \multirow{2}{*}{ Thrombocytes Length $(\mu)$} \\
\hline & $5.9146-6.6654$ & \pm 1.0052 & 6.2900 & 30 & F & \\
\hline \multirow{2}{*}{0.887} & $4.2328-4.9472$ & \pm 0.9565 & 4.5900 & 30 & M & \multirow{2}{*}{ Thrombocytes Width $(\mu)$} \\
\hline & $4.2401-5.0079$ & \pm 1.0282 & 4.620 & 30 & $\mathrm{~F}$ & \\
\hline \multirow{2}{*}{0.776} & $20.035-25.367$ & \pm 7.1405 & 22.7013 & 30 & M & \multirow{2}{*}{ Thrombocytes Size $\left(\mu^{2}\right)$} \\
\hline & $20.381-26.055$ & \pm 7.5972 & 23.2187 & 30 & $\mathrm{~F}$ & \\
\hline
\end{tabular}

*P value of less than 0.05 indicates a significant difference between the compared means of male and female tortoises. 
two lobes were connected with a narrow band of connective tissue. In a section examined under low power, the parenchyma of the tortoise liver is seen to be composed of intersinusoidal cords of hepatocytes (Figs. 4 and 5). The parenchymal cells (hepatocytes) arranged as cords of cells with vascular sinusoid spaces between the cords. The cords radiate from central vein which are the centers of the classic hepatic lobules (Fig. 4). Hepatic cells were polygonal and of different sizes and their nuclei were spherical or ovoid (Figs. 5 and 6). The portal areas (hepatic triad) present and comprise branches of portal vein, hepatic artery and bile duct, often also with a lymphatic vessel, lying in a small amount of connective tissue (Figs. 6 and 7). Within the lobule, there is a fine meshwork of reticular and collagenous fibers around the sinusoids and within the perisinusoidal spaces (Fig. 8).

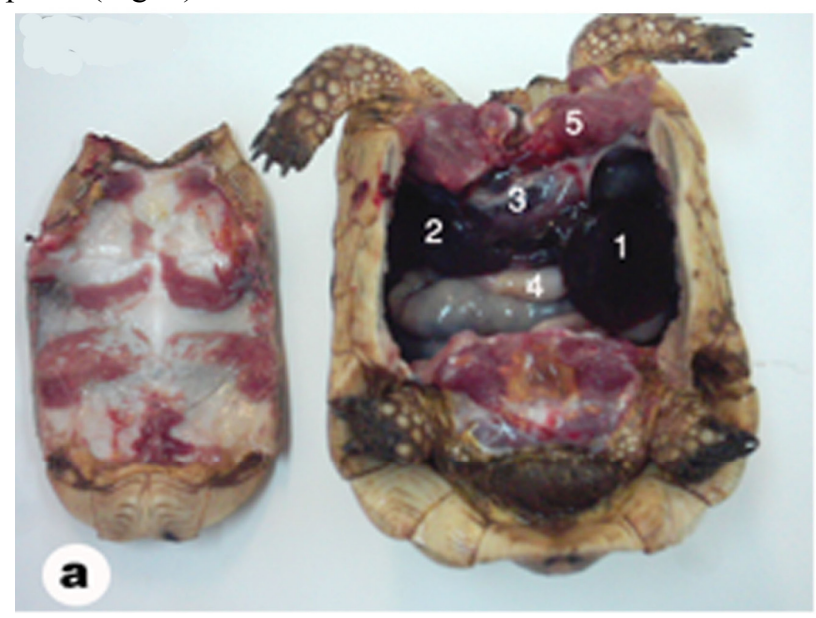

Fig. (3). Photograph showing the Viscera of the tortoise. 1- Left lobe of liver, 2- Right lobe of liver, 3- Heart, 4- Stomach, 5Pectoralis muscles.

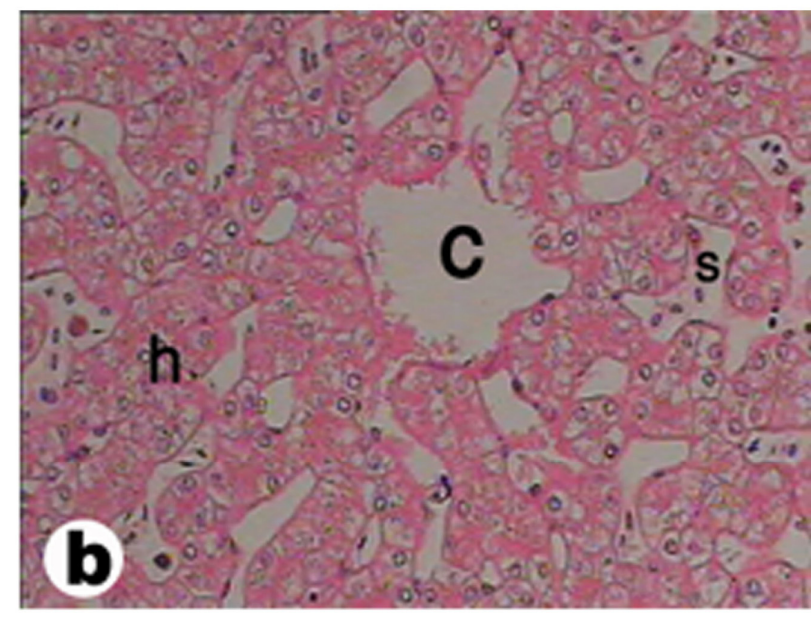

Fig. (4). Light micrograph of liver tissue from tortoise. c- Central vein, h- sheets of hepatocytes, s- Blood sinusoid containing red blood cells. $(\mathrm{H} \& \mathrm{E} \times 400)$

\section{Morphological and Histological Results of the Spleen}

The spleen of tortoise is the most important immune organ and it is the body's largest filter of the blood. The spleen appeared grossly as round or oval structure. It was located in the abdomen of tortoise under the stomach

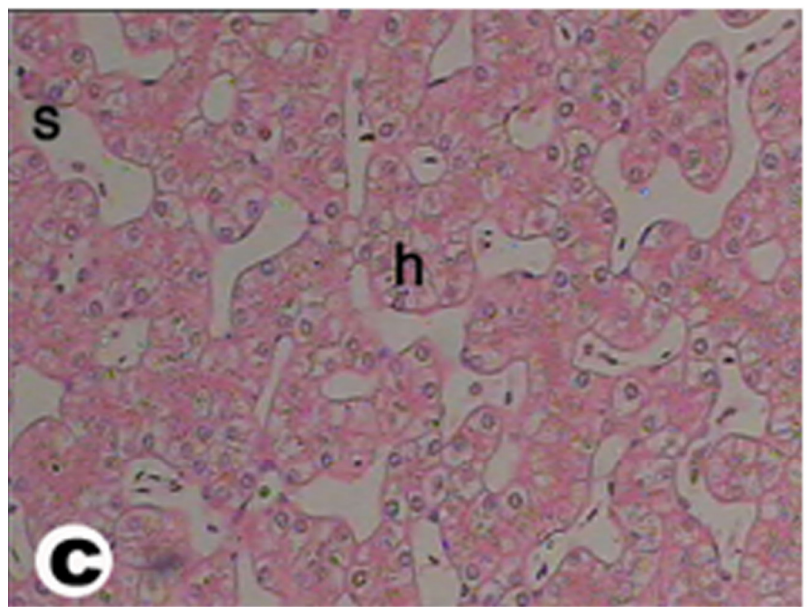

Fig. (5). Light micrograph of liver tissue from tortoise showing cords of hepatocytes (h) with their nuclei and the blood sinusoids (s). $(H \& \mathrm{E} \times 400)$.

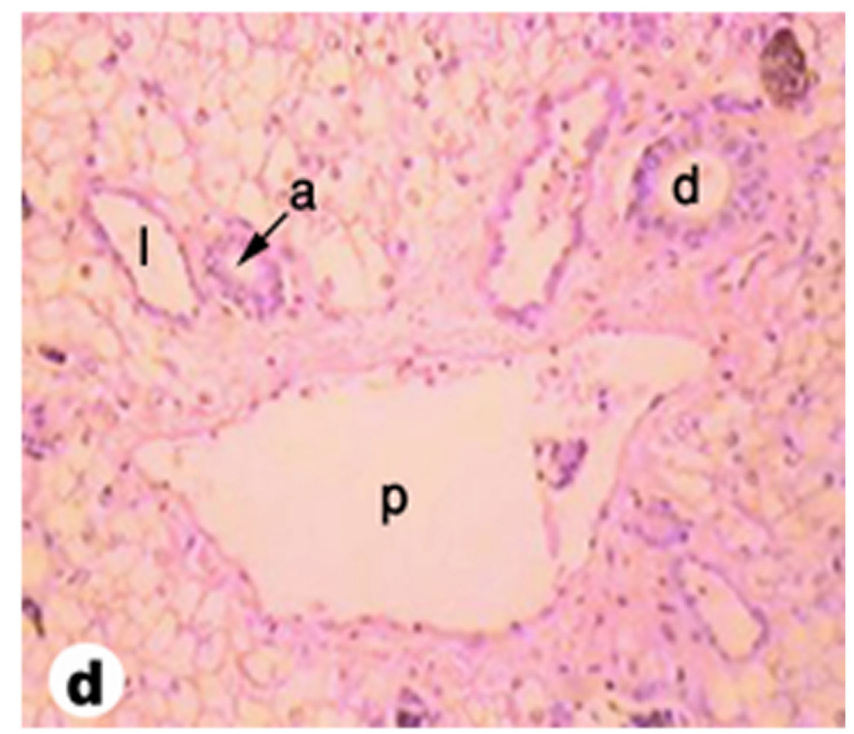

Fig. (6). Light micrograph of tortoise liver showing the portal area with a branch of the portal vein (p), a branch of the hepatic artery (a), a bile duct (b) and a lymphatic vessel (1). (H \& E × 160).

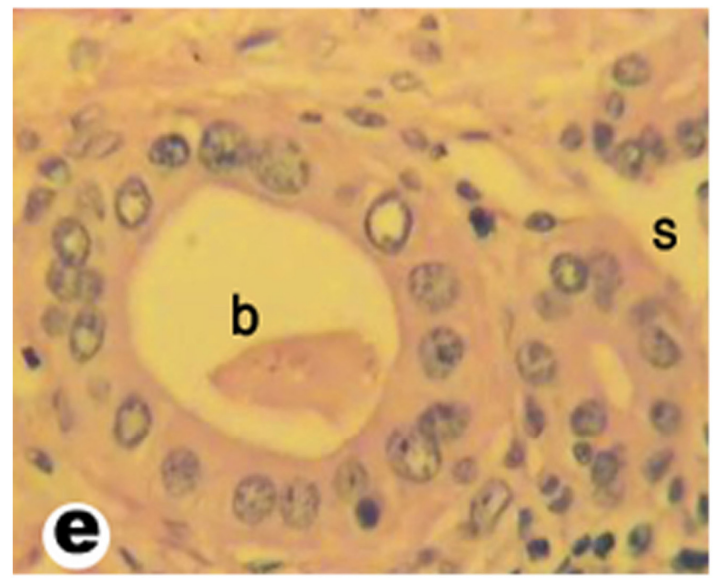

Fig. (7). High magnification of light micrograph of tortoise liver showing the bile duct (b) and sinusoids (s). (H \& E ×800). 
(Fig. 9). Sections of tortoise spleen showed normal splenic structure. The organ was surrounded by a fibrous capsule of connective tissue, stemming from which are trabeculae that support the large vasculature (Fig. 10). The connective tissue capsule and trabeculae extending from it were clearly identified. The parenchyma (splenic pulp) formed of lymphoid tissue and is of two distinct types; white and red pulps (Fig. 11). The white pulp composed of central arteriole surrounded with aggregation of lymphoid tissues (Figs. 12, 13 and 16). The red pulp is more abundant and formed of vascular sinuses filled with blood cells (Figs. 12, 14 and 15).

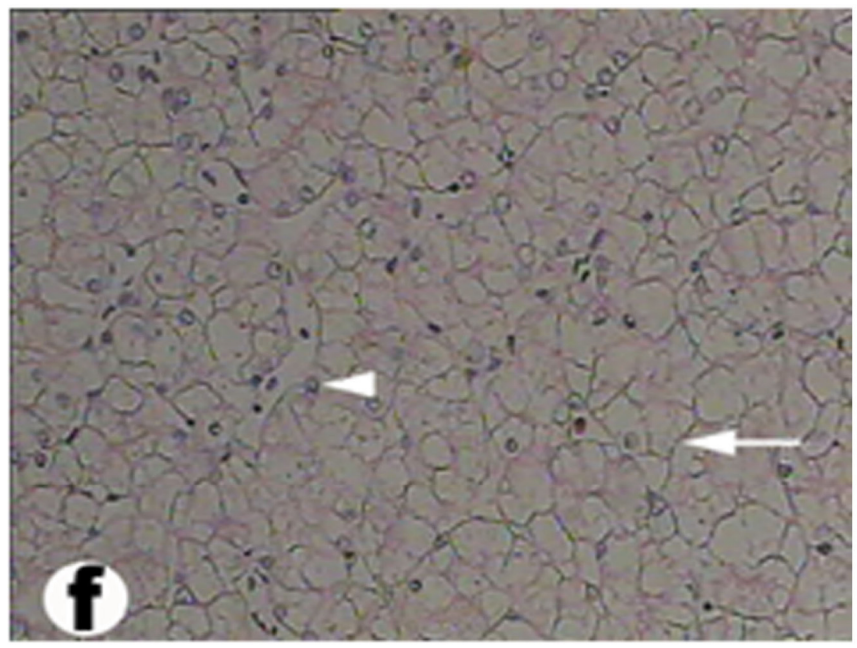

Fig. (8). High magnification of Light micrograph of the liver parenchyma showing a typical reticulum (arrow) and hepatocytes (arrow heads). ( $\mathrm{H} \& \mathrm{E} \times 400)$.

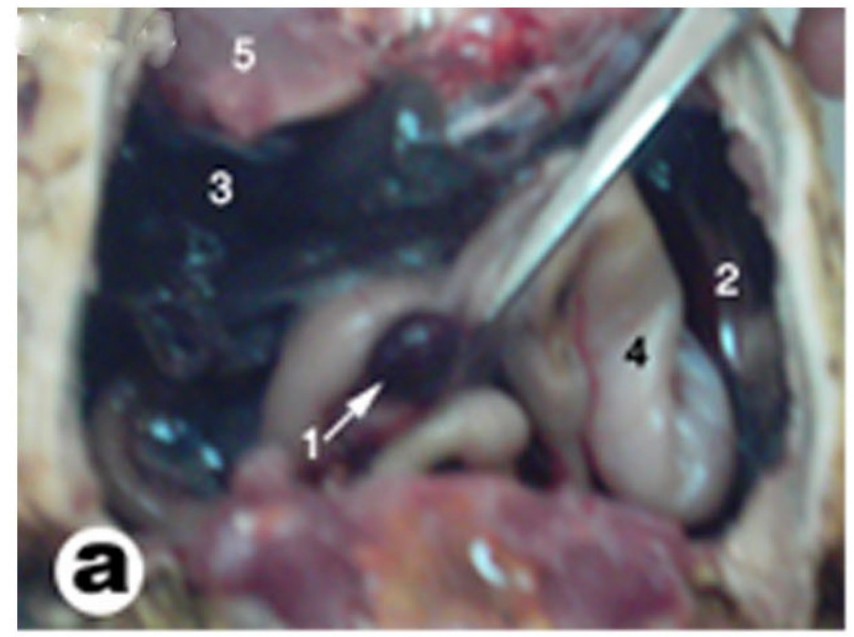

Fig. (9). Topography of the liver and spleen of tortoise. 1- spleen, 2- left lobe of liver, 3- Right lobe of liver, 4- stomach, 5- Pectoralis muscles.

\section{DISCUSSION}

This study represents the first attempt to develop baseline health parameters for the desert tortoise Testudo graeca. The original goal for this study was to study the morphological characteristics of the blood cells and the anatomy of the liver and spleen. The data presented will provide the veterinary clinician with specific hematological data which will allow for a more comprehensive medical assessment in tortoise clinical cases.
Our findings related to carapace and plastron measurements suggest that there is minimal variation in the size of the tortoises. It was interesting to note that the female tortoises were larger and heavier than the male tortoises in this study. Diaz-Figueroa [26] and McRae et al. [27] reported the same observations with gopher tortoise. In general, male tortoises are larger than female tortoises [28, 29]. This difference may be the result of older and larger male tortoises being removed from the population.

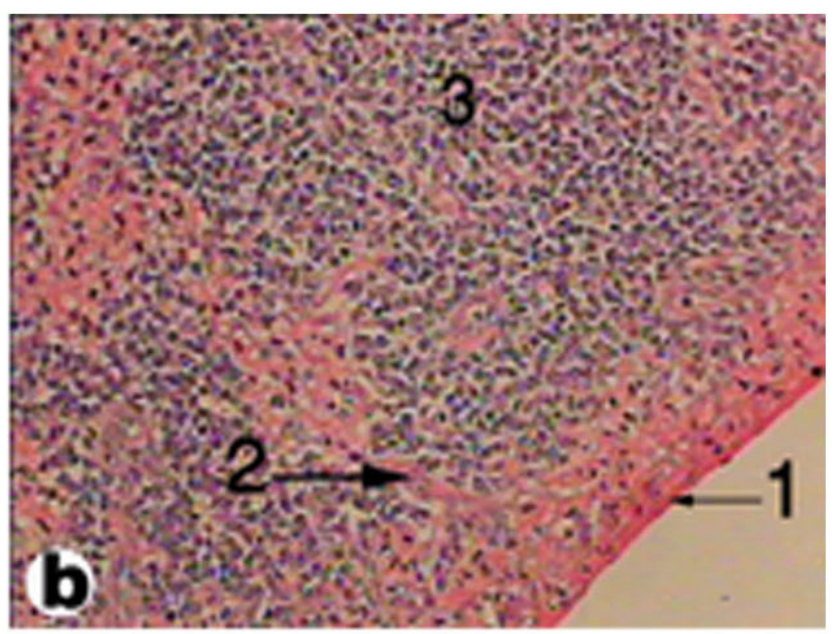

Fig. (10). Light micrograph of spleen tissue from tortoise. 1Capsule, 2- Trabecula, 3- Parenchyma. (H \& E ×200).

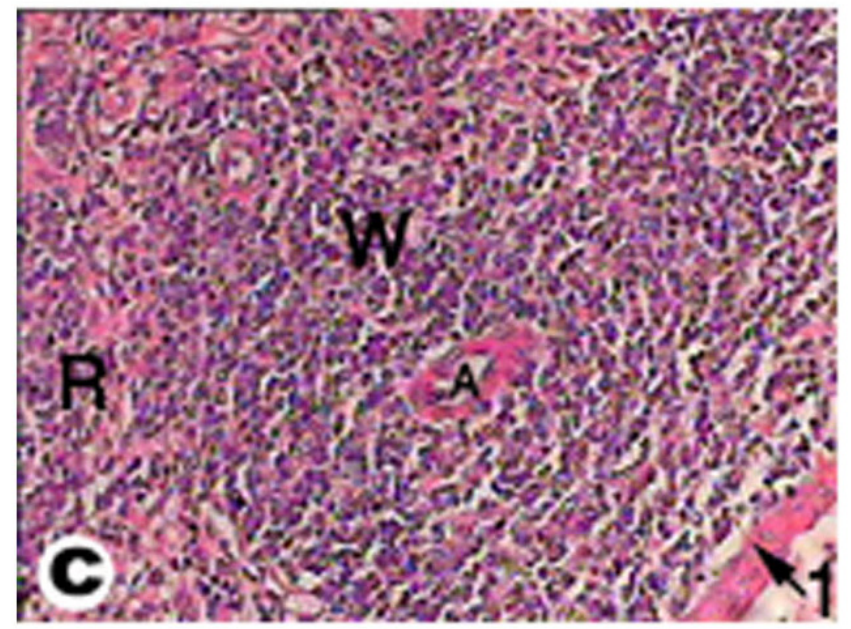

Fig. (11). Light micrograph of spleen tissue from tortoise. 1Capsule, A- Central arteriole, W- White pulp, R- Red pulp. (H \& E $\times 400)$.

Hematology and blood biochemical parameters are essential to assess the health and physiological status of stoic animals like the gopher tortoise. Although one hundred-sixty blood samples are routinely collected from tortoises to perform complete blood counts, morphologic criteria for distinguishing the various circulating blood cells have not been established in the desert tortoise Testudo graeca. Alleman et al. [13] described the morphological features and cytochemical staining characteristics of circulating blood cells for the desert tortoise. However, these same features also need to be described for the desert tortoise Testudo graeca. The hematological parameters measured in this study were considered to be within reference limits for 
captive chelonian species. The findings suggest that these tortoises are, in general, healthy. The complete blood counts in tortoises captured during the fall were significantly lower than in the spring. The same seasonal variation was noted in gopher tortoises from Florida [6]. Lower total white blood cell counts are not an uncommon finding in reptiles during the fall. As the environmental temperature decreases, the reptile's metabolic rate and immune function also decrease. Lymphocytes were the predominant white cell found in these tortoises. The lymphocytes play several important roles in the reptile, including producing antibodies and attacking foreign materials (natural killer cells).

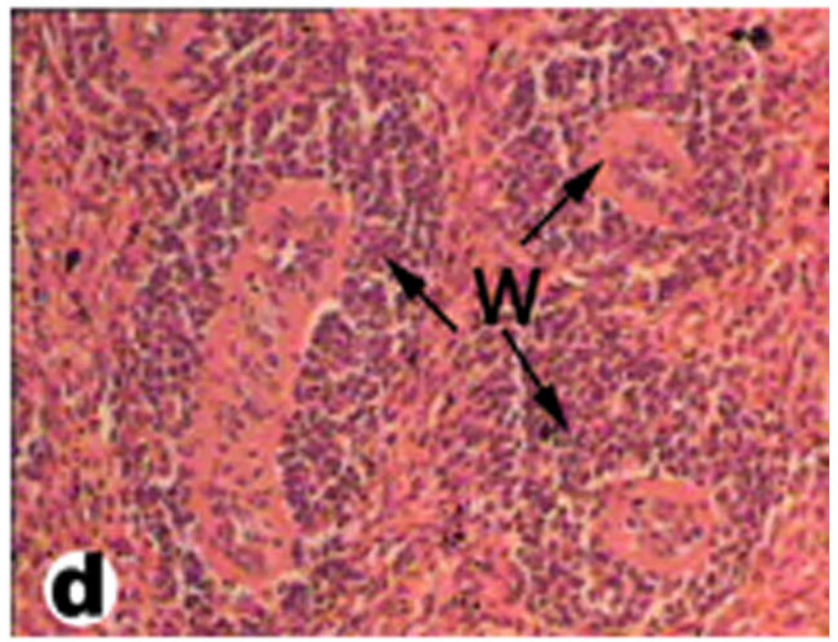

Fig. (12). Light micrograph of spleen tissue from tortoise showing three white pulps (W) in the splenic parenchyma. $(\mathrm{H} \& \mathrm{E} \times 400)$.

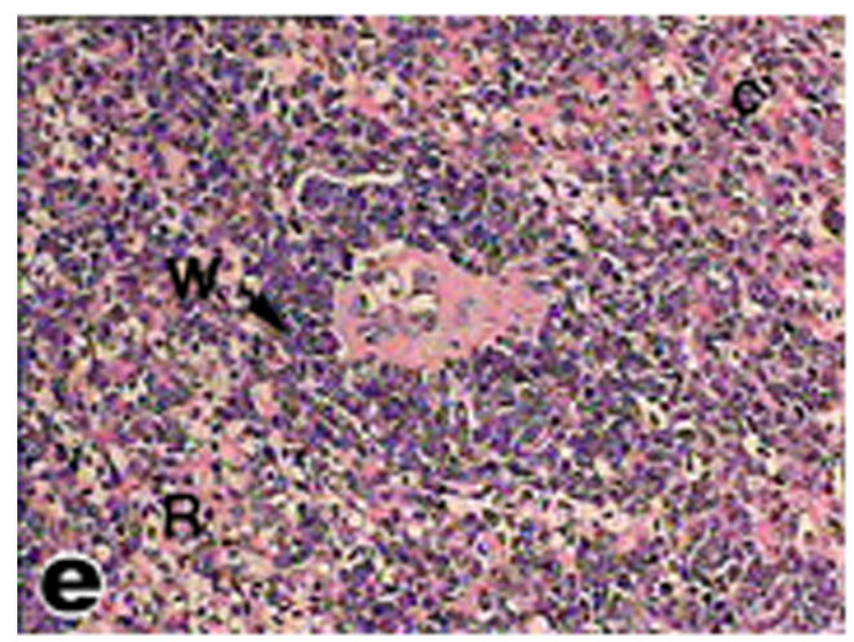

Fig. (13). Light micrograph of spleen tissue from tortoise showing one white pulp (W) and the rest of the parenchyma is red pulp (R), consisting of cellular cords (c) and numerous venous sinuses. (H \& $\mathrm{E} \times 400)$.

Erythrocytes are morphologically similar among various species of reptiles [30]. The mature erythrocytes were nucleated ellipsoidal cells with pink stained cytoplasm, which are consistent with that reported in desert tortoise [13], in European pond turtles [24] and in green turtles [31]. The erythrocyte measurements are also in agreement with the results of Colagar and Jafari [32] and $\mathrm{Ug}^{2}$ urtas et al. [23].

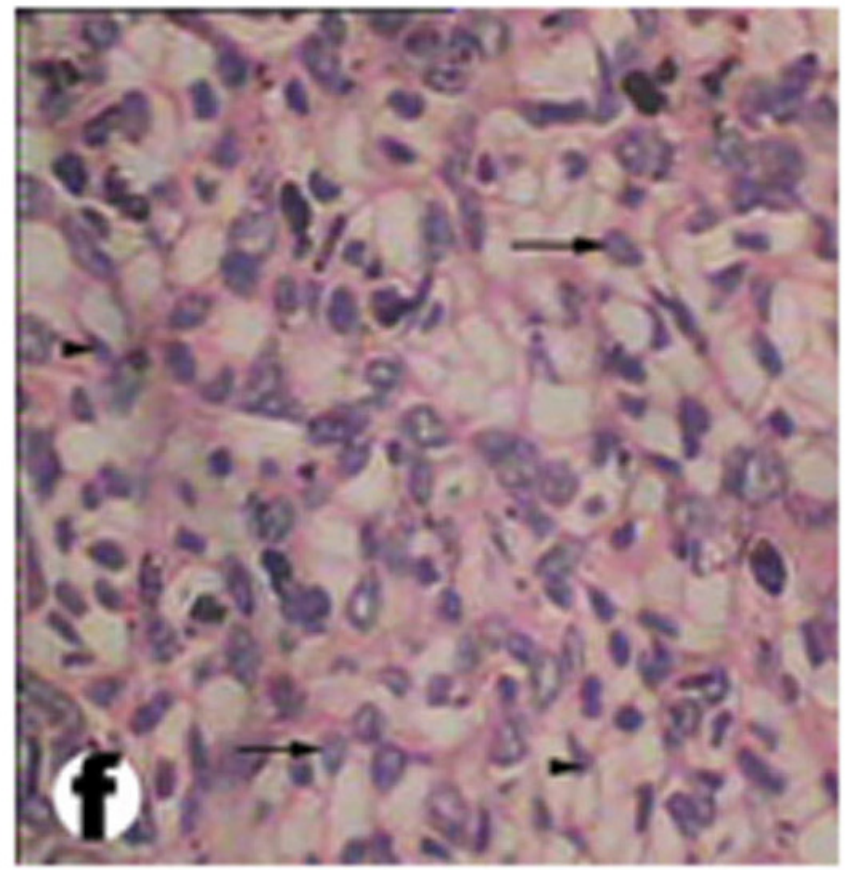

Fig. (14). High magnification of Light micrograph of red pulp of the spleen, showing a typical reticulum and its associated reticular cells. Within the meshes are lymphocytes (arrows), fibroblasts and free macrophages (arrow head). ( $\mathrm{H} \& \mathrm{E} \times 800$ ).

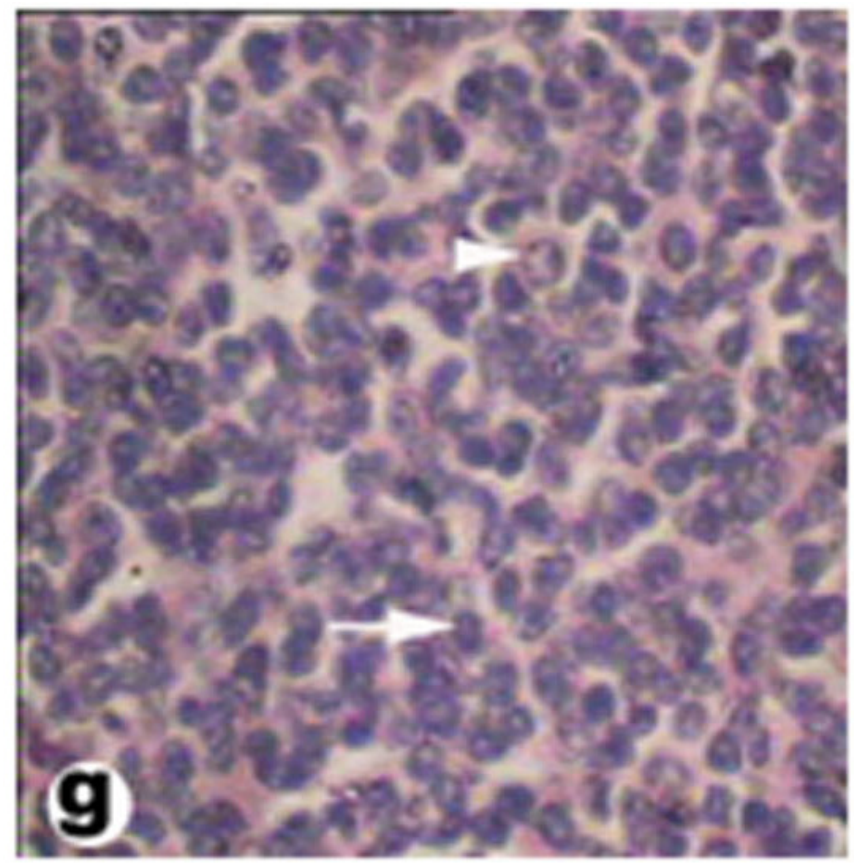

Fig. (15). High magnification of Light micrograph of white pulp of the spleen, showing lymphocytes (arrow) and plasma cell (arrow head). ( $\mathrm{H} \& \mathrm{E} \times 800)$.

Some erythrocytes in the desert tortoise Testudo graeca had small intracytoplasmic inclusions. Similar round or irrigular intracytoplasmic inclusions have been described in the erythrocytes of several species of reptiles [33], in water dragon [34], in desert tortoise [13], in Juvenile Loggerhead Sea turtle [35] and in green sea turtles [36]. These intracytoplasmic inclusions were considered ultrastructurally 
to represent a degenerate organelle, possibly mitochondria [13]. In mammals, the nuclear lobulation is distinct, but this is not a prominent feature of turtle granulocytes.

Saint Girons [30] reported the presence of eosinophils, azurophils, neutrophils and plasma cells in reptiles. While, Sypek and Borysenko [37] reported eosinophils, heterophils, basophils, monocytes and lymphocytes. According to Canfield [38], the mammalian neutrophil is equivalent to the non mammalian heterophil. The morphological characteristics obtained by light microscopy of erythrocytes, thrombocytes, monocytes and lymphocytes were similar to those seen in other reptilian species [13, 36, 39].

The heterophil contains large, eosinophilic, ovoid, cytoplasmic granules with eccentric nucleus. These features are similar to those described for heterophils from Loggerhead Sea turtle [35] and green sea turtles [36]. However, other reptiles, particularly the snakes, yellow rat snake (Elaphe obsolete quadrivittata), eastern diamond back rattle snake (Crotalus adamanteus) and the king cobra (Ophiophagus hannah), had two morphological variations of heterophils by electron microscope; one variant contained a homogenous population of electon-dense intracytoplasmic granules and the other variant contained some granules that were electron dense whereas other granules similar in size and shape, suggesting different developmental stages of heterophils in the circulation [40, 41].

The eosinophil is distinguished by its round, eosinophilic cytoplasmic granules and the nucleus is round to oval, single or bi-lobed, and eccentrically placed within the cytoplasm. Eosinophils from desert tortoise were homogenous in size as in Loggerhead turtles [35], unlike eosinophils from green turtles [36] and Kemp's ridley turtles [42], which are large as well as small. Work et al. [36] suspected that the large eosinophils in green turtles represent activated cells in response to a parasitic infestation or other inflammatory stimulus.

The lymphocyte contains a small amount of blue staining cytoplasm and a round nucleus with a fine reticular pattern. These characteristics are similar to those described for heterophils from loggerhead sea turtle [35] and green sea turtles [36].

The monocyte contains a large amount of light blue-gray, finely granular or vacuolated cytoplasm, and an oval or indented nucleus. These characteristics are similar to those described for heterophils from Loggerhead Sea turtle [35] and green sea turtles [36]. However, other authors didn't identify monocyte in the blood of green turtles $[43,44]$ or Kemp's ridley turtles [42].

The thrombocytes were oval-shaped cells contain round, densely staining nucleus, although sometimes were observed round thrombocytes, similar to those seen in Loggerhead Sea turtle [35] and green sea turtles [36].

Concerning the morphology of the liver of the desert tortoise Testudo graeca, the results of the present work have many similarities to that described by Marycz and Rogowska [22] in Horsefield's (Testudo horsefieldi) and Hermann's tortoises (Testudo hermanni). Generally, within Testudinata, the liver had very similar shape and morphology. The differences most often concerned with the mass of this organ, which at carnivorous tortoises was relatively greater [45]. While this organ could appeared as long single lobe and spindle - shaped organ at snakes, or the multilobe form at other reptiles [21].

Concerning the morphology of the spleen of the desert tortoise Testudo graeca, our results revealed that it has red and white pulps that come in agreement with that mentioned by Borysenko [46], in the snapping turtle (Chelydra serpentine).

The liver and spleen of tortoise differs from that of mammals and similar to reptiles which may contribute the understanding of evolutionary requirements of the species.

In conclusion; this study is the first attempt to characterize the health status of the desert tortoise Testudo graeca. In general, our findings suggest that these tortoises are in good health. However, some of our findings suggest that these keystone species should continue to be monitored to protect them into the future.

\section{REFERENCES}

[1] Muro J, Ramis A, Pastor J, Velarde R, Tarres J, Lavin S. Chronic rhinitis associated with herpesviral infection in captive spurthighed totoise from Spain. J Wildl Dis 1998; 34: 487-95.

[2] Jacobson ER, Origgi F. Use of serology in reptile medicine. Semin Avian Exotic Pet Med 2002; 11(1): 33-45.

[3] Christopher MM, Berry KH, Henen BT, Nagy KA. Clinical disease and laboratory abnormalities in free-ranging desert tortoises in California (1990-1995). J Wildl Dis 2003; 39 (1): 35-56.

[4] Rosskopf WJ. Normal hemogram and blood chemistry values for California desert tortoises. Vet Med Small Anim Clin 1982; 77: 857.

[5] Jacobson ER, Schumacher J, Green M. Field and clinical techniques for sampling and handling blood for hematologic and selected biochemical determinations in desert tortoise, Xerobates agassizii. Copeia 1992; 1: 237-41.

[6] Taylor RW, Jacobson ER. Hematology and serum chemistry of the gopher tortoise, Gopherus polyphemus. Comp Biochem Physiol 1982; 72: 425-8.

[7] Christopher MM, Brigmon R, Jacobson ER. Seasonal alterations in plasma B-hydroxybutyrate and related biochemical parameters in the desert tortoise (Gopherus agassizii). Comp Biochem Physiol 1994; 108: 303-10.

[8] Dickinson VM, Duck T, Schwalbe CR, Jarchow JL. Health studies of free ranging Mojave Desert tortoises in Utah and Arizona. Arizona Game and Fish Department Research branch Technical Report No. 21, Phoenix, Arizona, 1995; 70-9.

[9] Dickinson VM, Jarchow JL, Trueblood MH. Health studies of freeranging Sonoran Desert tortoises in Arizona. Arizona Game and Fish Department Research branch Technical Report No. 24, Phoenix, Arizona, 1996.

[10] Dickinson VM, Jarchow JL, Trueblood MH. Hematology and plasma biochemistry reference range values for free ranging desert tortoises in Arizona. J Wildl Dis 2002; 38: 143-53.

[11] Christopher MM, Wallis I, Berry KH. cvAn International Conference. Abbema JV, Ed. Wildlife conservation society turtle recovery program and the new york turtle and tortoise society, New York 1997; pp. 76-82.

[12] Jacobson ER, Gaskin IM, Brown MB, et al. Chronic upper respiratory disease of free-ranging desert tortoises (Xerobates agassizii). J Wildl Dis 1991; 27: 296-316.

[13] Alleman AR, Jacobson ER, Raskin RE. Morphologic and cytochemical characteristics of blood cells from the desert tortoise (Gopherus agassizii). Am J Vet Res 1992; 53:1645-51.

[14] Knotková Z, Doubek J, Knotek Z, Hájková P. Blood cell morphology and plasma biochemistry in russian tortoises (agrionemys horsfieldi). Acta Vet Brno 2002; 71:191-8.

[15] Ryerson DL. Separation of two acidophilic granulocytes of turtle blood, with suggested phylogene relationships. Anat Rec 1943; 85: $25-46$. 
[16] Hartman FA, Lessler MA. Erythrocyte measurements in fishes, amphibian, and reptiles. Biol Bull Mar Biol Lab 1964; 126: 83-8.

[17] Thorson TB. Body fluids partitioning in reptilia. Copeia 1968; 592601.

[18] Friar W. Turtle family relationships as determined by serological tests. In: Leone CA, Ed. Taxonomic Biochemistry and Serology. New York: Ronald Press 1964; pp. 535-44.

[19] Seal US. Vertebrate distribution of serum ceruloplasmin and sialic acid and the effects of pregnancy. Comp Biochem Physiol 1964; 13: $143-59$.

[20] Jackson OF. Chelonians. In: Beynon Manualof exotic pets, P.H., Cooper JE (Eds.). British Small Animal Veterinary Association, Cheltenham, UK 1991; pp. 221-43.

[21] Webster D Webster M. Comparative vertebrate morphology. Academic Press: London and New York 1974.

[22] Marycz K, Rogowska K. The liver morphology and topography of horsfields (testudo horsfieldi) and hermanns (t. hermanni) terrestrial tortoises. Electron J Polish Agricultural Universities, 2007; 10: 1-9.

[23] Ug urtas SH, Sevinc M, Yldrmhan H. Erythrocyte size and morphology of some tortoises and turtles from turey. Zoologic Stud 2003; 42(1): 173-78.

[24] Metin K, Türkozan O, Kargin, F, Basimogglu Y, Taskavak E, Koca S. Blood cell morphology and plasma biochemistry of the captive european pond turtle (Emys orbicularis). Acta Vet Brno 2006; 75: 49-55.

[25] Drury RAB, Wallington EA. Carleton's histological techniques. $5^{\text {th }}$ ed. Oxford: New York. London. 1980.

[26] Diaz-Figueroa O. characterizing the health status of the louisiana gopher tortoise (gopherus polyphemus). Master thesis, the Graduate Faculty of the Louisiana State University and Agricultural and Mechanical College 2005

[27] McRae WA, Landers JL, Cleveland GD. Sexual dimorphism in the gopher tortoise (Gopherus polyphemus). Herpetologica 1981; 37: 46-52.

[28] Landers JL, McRae WA, Garner JA. Growth and maturity of the gopher tortoise in southeastern Georgia. Bull Fla St Mus Biol Sci 1982; 27(2): 81-110.

[29] Smith LL. Nesting ecology, female home range and activity, and population size-class structure of the gopher tortoise, Gopherus polyphemus, on the Katharine Ordway Preserve, Putnam County. Florida. Bull Fla Mus Nat Hist 1995; 37: 97-126.

[30] Saint GMC. Morphology of the circulating blood cells. In: Gans C, Ed. London: Academic Press Inc. 1970; pp. 73-90.

[31] Samour HJ, Risley D, March T, Savage B, Nieva O, Jones DM. Blood sampling technique in reptiles. Vet Record 1984; 114: 47276.
[32] Colagor H, Jafari N. Red blood cell morphology and plasma proteins electrophoresis of the european pond terrapin (EMYS ORBICULARIS). Afr J Biotechnol 2007; 6 (13): 1578-81.

[33] Campbell T W. Hematology of reptiles. In: Thrall MA, Baker DL, Eds. Veterinary hematology and clinical chemistry. Philadelphia, PA: Lippincott Williams and Wilkins 2004; pp. 259-76.

[34] Mayer J, Knoll J, Innis C, Mitchell MA. Characterizing the hematologic and plasma chemistry profiles of captive chinese water dragons (Physignathus oncincinus). J. Herpetol Med Surg 2005; 15(3): 219-23

[35] Casal AB, Freire F, Bautista-Harris G, Arencebia A, Oros J. Ultrastructural characteristics of blood cells of juvenile loggerhead sea turtles (caretta caretta). Anat Histol Embryol 2007; 36: 332-35.

[36] Work TM, Raskin RE, Balazs GH, Whittaker SD. Morphologic and cytochemical characteristics of blood cells from Hawaiian green turtles. Am J Vet Res 1998; 59: 1252-7.

[37] Sypek J, Borysenko M. Reptiles. In: Rowley AF, Ratcliffe NA, Eds. Vertebrate blood cells. Cambridge, England: Cambridge University Press 1988; pp. 211-56.

[38] Canfield PJ. Comparative cell morphology in the peripheral blood film from exotic and native animals. Aust Vet J 1998; 76: 793-800.

[39] Egami MI, Sasso WS. Cytochemical observations of blood cells of Bothrops jararaca (Reptilia Squamata). Rev Bras Biol 1988; 48: 155-9.

[40] Bounous DI, Dotson TK, Brooks RL, Ramsay EC. Cytochemical staining and ultrastructural characteristics of peripheral blood leucocytes from the yellow rat snake (Elaphe obsoleta quadrivitatta). Comp Haemathol Int 1996; 6: 86-91.

[41] Alleman AR, Jacobson ER, Raskin, RE. Morphologic, cytochemical staining and ultrastructure characteristics of blood cells from eastern diamondback rattlesnake (Crotalus adamanteus). Am J Vet Res 1999; 60: 507-14.

[42] Cannon MS, Freed DA, Freed PS. The leukocytes of the roughtail gecko Cytopodion scabrum: a bright-field and phase-contrast study. Anat Histol Embryol 1996; 25: 11-14.

[43] Aguirre AA, Balazs GH, Spraker TR, Gross TS. Adrenal and hematological responses to stress in juvenile green turtles (chelonian mydas) with and without fibropapillomas. Physiol Zool 1995; 68: 831-54.

[44] Wood FE, Ebanks GK. Blood cytology and hematology of the green sea turtle, Chelonia-mydas. Herpetologica 1984; 40: 331-6.

[45] Crile G, Quiring D. A record of the body weight and certain organ and gland of 3690 animals. Ohio J Sci 1940; 5: 219-59.

[46] Borysenko M. Changes in spleen histology in response to antigenic stimulation in the snapping turtle (chelydra serpentina). J Morphol 1976; 149 (2): 224-41.

(C) Suga and Nishio; Licensee Bentham Open.

This is an open access article licensed under the terms of the Creative Commons Attribution Non-Commercial License (http://creativecommons.org/licenses/by-nc/ $3.0 /$ ) which permits unrestricted, non-commercial use, distribution and reproduction in any medium, provided the work is properly cited. 